\title{
Current Researches on the Protection of Exterior Wood from Weathering ${ }^{1}$ (iํ료
}

\author{
Yeong-Suk Kim $\mathbb{D}^{2, \dagger}$
}

\begin{abstract}
A review of research trends on wood surface protection for exterior use obtained the following conclusions: It has been reported that inorganic compounds such as chrome and copper used as wood preservatives can protect wood from weathering. It has been shown that precoating with hydrophobic substances such as wax and oil, UV absorbers, and HALS (Hindered Amine Light Stabilizers) enhances weathering resistance on the surface of ACQ-treated wood. Opaque coatings of paint/stains and semitransparent stains on the surface of preservative treated wood can increase the synergistic effects on prevention of weathering deterioration. Also the need for repainting periodically for the protection of the preservative treated wood surface has also been suggested. $\mathrm{ZnO}$ or $\mathrm{TiO}_{2}$ of fine particles, metal ions such as $\mathrm{Co}, \mathrm{Cr}, \mathrm{Fe}, \mathrm{Mn}, \mathrm{Ni}$ and $\mathrm{Ti}$, and UV absorbers such as tris-resorcinol triazine derivatives, triazine and benzotriazole were introduced as additives for preventing UV in the transparent coating on wood. Several reports showed that chemical modification such as methylation, acetylation, or alkylations have made some increases the effects of preventing weathering with the increasing weight gain of chemical formulas. In heat-treated wood, there were various contradictory reports on the resistance of weathering, and there were some other reports emphasizing the necessity of painting with UV resistance, which leads to the necessity of more advanced studies.
\end{abstract}

Keywords: weathering, wood surface protection, exterior use, preservative treatment, wood coating

\section{INTRODUCTION}

It is predicted that the use of wood will increase even more than before as shown by the recent establishment of <The Social Contribution Type Operation Standards for Forest Carbon Offsets>, and the Article of the Enactment of the same titled act and the promotion of the use of wood products as a type of businesses that offset forest carbon (Korea Forest Service, Regulation 2016-2). Also, despite the recession in the construction market, the wooden housing market has shown a consistent growth rate with some $12 \%$ over the previous years in terms of the number of wooden houses that started to building in 2016 (The Korea wood newspaper, 2017). A 2017 survey on the weathering of exterior wood from 23 wooden houses of 5 to 23 years old in South Korea showed that most of the exterior wood showed various types of weathering deterioration (Kim et al., 2017). Discoloring was considered to be the most frequent deterioration of

\footnotetext{
${ }^{1}$ Date Received August 14, 2018, Date Accepted August 27, 2018

2 Department of Forest Products and Biotechnology, College of Forest Science, Kookmin University, Seoul 02707, Republic of Korea

† Corresponding author: Yeong-Suk Kim (e-mail: yskim@kookmin.ac.kr, ORCID: 0000-0002-0221-5764)
} 
weathering, and there appeared some numerous splits and cracks on the surface; and in the worst case, there was internal decay resulting from surface cracks. Most wood species used in South Korea were imported softwoods, like the Douglas fir, SPF, and Radiata pine as well as domestic larch, and the artificially accelerated weathering test showed that, within 30 days after the exposure, considerable weathering deterioration, such as discoloring was detected (Shin et al., 2018). Various types of wooden buildings including log houses, Hanok (Korean traditional houses), and light-frame structures have shown weathering deterioration, and in case of wood sidings, window frames, fascia boards, decks exposed to the outdoors, severe weathering deteriorations were appeared. Furthermore, it has been pointed out that many weathering effects have been occurred not only on southward members, but also on members in other locations, and that protection technology from surface weathering should be considered important for exterior wood members in South Korea (Kim et al., 2017). Particularly, there have been several research reports on weathering in the domestic environment, which pointed out the phenomena of wood discoloring or changes in chemical components (Qi et al., 2016; Kim et al., 2009).

According to the domestic and foreign research trends on environmental factors in weathering of wooden parts, the important causes include sunlight radiation, like UV, IR, or visible rays, oxygen, water, heat, pollutants, fine dust by wind, and microorganisms (Kim, 2017; Qi et al., 2016; Rowell, 2013, Kim et al., 2003a, 2003b). There have been various studies that aimed to protect the surface of wood from weathering due to the above actors (Nejad \& Cooper, 2017; Shoubo, 2017; Nejad, 2015; Rowell, 2013). Wood surface protecting technologies are methods that can control weathering factors, like sunlight, moisture or microorganisms, including surface coating, wood preservatives or resin treatment, chemical modifications and heat treatment
(Nejad et al., 2017; Shoubo, 2017; Tomak et al., 2014; Rowell, 2013). In addition, wood weathering deterioration, such as discoloring or surface roughness, tends to appear remarkably within from several months to two years so that the surface protection treatment is often performed right after the installation of wooden parts, and several studies have proposed the repainting for better maintenance (Ishikawa et al., 2017; Kataoka et al., 2011a; Kataoka et al., 2011b).

This study aimed to analyze the research trends, by a literature review, on various protection technologies for the wood surface from weathering factors. Specifically, the main concern was to investigate the research results subjected to the weathering prevention of wood preservatives, wood surface treatment for leaching prevention of wood preservatives and enhancement of surface protection from weathering, various additives and coating techniques, chemical modification techniques, and heat treatments for the maintenance of aesthetic quality of wood and surface protection.

\section{WOOD PRESERVATIVE TREATMENT}

\subsection{Surface protection of wood preservative from weathering}

Wood preservatives are usually used to promote the safety in the use of wood and the increase in service life, by protecting wood from wood destroying fungi and insects (Kim et al., 2004). Since weathering of wood is usually caused by photochemical reactions with lignin or extractives on the outermost surface layer, in many cases, wood preservative treatments may not protect wood completely from UV and moisture. However, it has been reported that chemical components of wood preservatives as a fungicide or insecticide allow protection of wood surface from UV, moisture and other weathering factors. This chapter includes a review of 
researches that show such surface protection effects of wood preservatives from weathering.

Inorganic compounds used as wood preservatives can protect wood surface from weathering by UV (Rowell, 2013). Feist and Williams (1991) reported that CCA (Chromated Copper Arsenate)-treated Southern pine showed protecting effects from weathering, and that pressure treatment with CCA would inhibit weathering more than the surface treatment, and they also pointed out that the more absorption of wood preservatives and the deeper penetration into the wood enhance protecting ability from weathering. Besides, various research literatures have concerned about the weathering protection effects of CCA-treated wood (Nejad \& Cooper, 2011; Evans et al., 1992; William \& Feist, 1985; Hon \& Chang, 1985). It has been reported that the key weathering protection role by CCA would result from the formation of chromate ester by the reaction of inorganic compounds in the CCA with lignin, which inhibit light absorption, and those increases hydrophobicity and hinders the absorption of UV (Bull, 2001; Evans et al., 1994; Evans and Schmalzl, 1989, Chang et al., 1982; Pizzi, 1980;). Particularly, CCAtreated wood containing chrome was shown to be superior in the waterproofing property and weathering inhibition effect to ACQ (Alkaline Copper Quat.) or $\mathrm{CuAz}$ (Copper Azole)-treated wood (Nejad \& Cooper, 2011). It has also been reported in Korea that the treated wood with water-borne wood preservatives, like CCA, ACQ and CuAz showed less lignin decomposition than untreated wood, as well as higher resistance to weathering (Kim et al., 2003a, 2003b).

Archer \& Preston (2006) introduced the weathering inhibition effect of copper in wood preservatives, and others also reported that, in case of ACQ, CuAz and $\mathrm{Cu}$-ehtanolamine, $\mathrm{Cu}$-amine complex compounds had a potential effect of preventing photo-oxidation of lignin by UV. And therefore, they would get higher weathering prevention effect than untreatment (Shoubo, 2017;
Nejad, 2015; Zhang et al., 2009; Timiz et al., 2005; Grelier et al., 2000; Cornfield et al., 1994; Liu et al., 1994). However, ACQ contains alkylammonium compounds, in which case hydrophilicity due to alkyl ammonium compounds swells wood and increases moisture penetration, resulting in increased UV penetration depth on the wood surface. As a result, photo-oxidation of lignin is promoted and the weathering prevention effect of ACQ may be decreased (Nejad \& Cooper, 2011). Therefore, coating on the ACQ treated wood would be required for enhancement of the resistance to weathering (Tanczos \& Schmidt, 2002; Ekstedt, 2002; Worringham, 1994). Particularly, Hon (2010) reported that free radical caused by the reaction between UV and wood components is increased by moisture, and that polarized water permeates deeper into the wood surface, leading to the swelling of cell walls and resulting in the growth of the UV permeation depth. This again leads to the increase in the generation of free radical and weathering of wood surface in the deeper layer. In other words, to protect wood surface from weathering, both UV and moisture on the wood surface should be controlled at the same time.

\subsection{Coating on the preservative treated wood}

There have been various studies on controlling hydrophilic property of ACQ-treated wood by enhancing waterproofing property and dimensional stability on the wood surface, using hydrophobic additives like wax or oil (Evans et al., 2003; Evans et al., 2009; Zahora, 2000; Christy et al., 2005; Cui \& Zahora, 2000, Nejad \& Cooper, 2010). Nejad \& Cooper (2011) conducted a natural weatherproof test for three years by coating various paint on the surface of the woods treated with CCA, ACQ and CuAz, and observed the absorptiveness, discoloring, surface cracking and others. They reported that water absorptiveness was higher with ACQ- and 
CuAz-treated wood than with CCA-treated wood. While CCA-treated wood showed better waterproofing property with oil-based paint than water-based paint, but ACQ and CuAz-treated wood did not show any significant differences between oil-based and water-based paint. Furthermore, compared to untreated wood, CCA, ACQ and CuAz-treated wood showed less discoloring, but there was no significant differences in surface cracking between treated and untreated woods, and the surface coating on the preservative treated wood would reduce surface cracking by 30 to $40 \%$, also reducing the weathering potential by surface cracking. Sivrikaya et al. (2017) reported that the semitransparent paint on the surface of $\mathrm{CuAz}$ treated wood would improve the synergy effect of suface protection from weathering. Kataoka et al. (2015) also proclaimed through the natural weathering test on $\mathrm{CuAz}$ and DDAC (Dimethyl Dodecyl Ammonium Chloride)treated Japanese cedar with the water-based \& oil-based paint on its surface for 108 months in Tsukuba, Ibaraki Prefecture, that semi-transparent paint on CuAz-treated wood exhibited excellent weathering protection effect by maintaining good surface quality for some 10 years. In other researches on coloring for preventing weathering of western redcedar, discoloring was reduced, but the occurrence of the dark spots, a typical symptom of weathering by microorganisms, were not improved (Stirling \& Landry, 2016). The most effective antiweathering coating on the surface of CCA-treated southern pine and Hem-fir as shown by the surfacetreatment test, using various types of paint was paint/stain coating with opaque coloring as well as semitransparent stain, showing that enough coating is essential for outside use (Feist \& Ross, 1995). Particularly, Ozgenc et al. (2012) reported that UV-absorber coated surface on the treated wood with micronized copper preservative was effective in pine wood, but there was no difference in colour stabilization and coating permeation in beech wood, indicating that the weathering protection effect of micronized copper preservative differs by wood species. Furthermore, Natale \& Vidal (2017) coated oil varnish and paint on the treated wood with water-borne preservative [CCB (Copper Chromated Boron)] and oil-borne preservative (IPBC \& Cypermethrin), and conducted a natural weathering test for eight months in Luiz Antonio, Brazil. The results showed that over $90 \%$ brightness variation and surface cracking in all test deck specimens, and only CCBtreated wood showed the least discoloring and surface cracking, indicating that preservatives with inorganic components would be effective in preventing weathering. Another natural weathering test with oriental beech and scots pine treated with copper or boron-based new preservatives such as Tanalith-E \& Adolit-KDS and coated with synthetic varnish and polyurethane varnish was conducted. The test results showed that the color change of all preservatives was lower than untreated specimens, and particularly, the specimen treated with Tanalith-E and coated with polyurethane varnish showed excellent weathering protection capabilities (Turkoglu et al., 2015). As such, it has been shown that while some wood preservatives with copper or chrome may protect weathering by UV or moisture, organic wood preservatives that do not contain metal substances would be difficult to prevent weathering without discoloration inhibitor or UV stabilizers (Schauwecker et al., 2009). Stiring \& Morris (2013) reported that weathering prevention effects could be acquired by finishing wood treated with carbon-based preservatives that do not have any metal substances with pre-coating, transparent or semi-transparent paint that uses organic UV absorbers or HALS (Hindered Amine Light Stabilizers) to control free radical. For the surface protection of treated wood with wood preservatives, the Forest Products Laboratory of the United States Forest Service proposed two surface coating techniques that allow for recoating every two years on the surface of the treated wood. The first coating 
was to thinly coat oil-based enamel, and for the second coating, water repellent agent and semi-transparent permeable stain was used (Knaebe, 2013).

\section{WOOD SURFACE PROTECTION BY COATING}

Coating is considered a useful method in protecting wooden surfaces from weathering defects. JAS S18, Standard Specification for Architectural Construction, published by the Architectural Institute of Japan, divided the exterior wood paint into colour finishing paint and semi-transparent finishing paint, and the latter was further divided into the film forming type and the penetrating finish type (Shoubo, 2017). Since color finishing coating forms opaque coating due to the color of the paint, the wood pattern on the surface is hidden below coating film. By the effects of the considerable UV protection due to the paint, it has superior protection from weathering comparing to semi-transparent finishing coating, however it could not control for the checking of the wood underneath the coating film, which makes it difficult to detect weathering or swelling (Shobu, 2017; Knaebe, 2013; Rowell, 2013). In fact, many of research reports focus on semi-transparent finishing agents and additives for the protection of the wood surface from weathering such as UV and water (Shoubo, 2017; Reinprecht \& Panck, 2015; Evans et al., 2016; , Isaji, 2016; Grull et al., 2014; Knaebe, 2013; Park \& Kim, 2013; Landry et al., 2013; Rowell, 2005, 2013; Landry \& Blanchet, 2012). Discussed issues in this chapter are the coating processes in the film forming type and the penetrating finish type for wood surface protection, including the effects of various additives.

\subsection{Coating for forming film}

Coating by forming film protects the surface of wood by forming a film. Materials used for film-forming coating are all types of paints, varsnishes, and lacquers (Nejad \& Cooper, 2017; Shoubo, 2017; Knaebe, 2013; Rowell, 2005).

Paints that are used for film-forming coating often contain coloring agent, which may contain colour or protect the surface from UV. It is known that the more the amount of coloring agent, the better the weathering protection effect. It offers as it can protect the wood surface from UV radiation, and it also offers a wide variety of colors to choose (Nejad \& Cooper, 2017; Rowell, 2005; Satas \& Traction, 2001). Due to the high amount of coloring agent, opaque paint can maintain its coating for about 10 years in outdoors, but semi-transparent coating that has lower weathering protection effects than opaque coating might enhance weathering protection effect with increasing of coating film thickness (Grull et al., 2014). Oil-based or alkyd paint is basically a suspension containing inorganic coloring agents in oil, and latex paint is a suspension of various latex resin and inorganic coloring agents (Khedkar et al., 2017). Particularly, the Forest Products Laboratory of the United States Forest Service recommends acrylic latex as the most superior material for protecting the surface of wood from the outside. It is reported that this latex paint is water-repellent with porous film to pass only moisture and higher durability than oil-based paint (Knaebe, 2013). Others have studied on the weathering protecting techniques using various polymers, reporting that addition of polyvinylidene fluoride (PVDF) to acrylic paint would improve surface protection effects in various softwoods (Landry et al., 2013; Landry \& Blanchet, 2012). Acrylic polymers are resistant to UV and not susceptible to weathering so that it offers good protection for wood surface for a long time. However, the water-soluble extracts contained in wood such as redwood or western redcedar may permeate out from the latex paint film. Some people have tried to use oil-based paint coating as the primary to prevent the extracts permeating, followed by acrylic 
latex paint, which get good results for the service life of surface coating for over 15 years (Knaebe, 2013; Rowell, 2005; Williams et al., 1999).

When weathering factors like UV or moisture cannot be controlled only by paint, and some additives that help to protect wood surface, such as inorganic materials, could be used along with paint. Particularly, inorganic metallic oxides like iron, titanium and zinc oxide can be used as additives to absorb or diffuse UV, and these materials give a good weathering protection from UV (Park \& Kim, 2013; Sharrock, 1990). But the use of these inorganic chemicals may be limited on transparent paint to maintain the natural color and pattern of wood as these materials cause yellowish coloring or discoloration under natural light (Aloui et al., 2007; Singh \& Dawson, 2003). One of the solutions to improve the transparency of inorganic particles and allow for transparent film coating is the nano sized metallic oxide particles. Some studies report that the use of fine inorganic particles can improves the transparency of additives and protections effect from weathering, and thus to offer UV protection effects equal to or better than organic UV absorbers or HALS (Auclair et al., 2011; Cristea et al., 2010; Liu et al., 2010; Yu et al., 2010; Weichelt et al., 2010; Pinnell, 2000; George et al., 2005). Ozgenc et al. (2012) reported that the artificially accelerated weathering test results on the Scots pine and European beech after applying transparent coating that contains micro-level $\mathrm{TiO}_{2}$ and Triazine UVA, showed the highest effect on the discoloring protection. Others reporting that the nano-level $\mathrm{ZnO}$ or $\mathrm{TiO}_{2}$ is mixed to water-based paint and is processed on black spruce shows the excellent weathering protection effects (Salla et al., 2012; Cristea et al., 2010). Additionally, the use of metal acetylacetonates, a composite of metallic ions like Co, $\mathrm{Cr}, \mathrm{Fe}, \mathrm{Mn}, \mathrm{Ni}$ and $\mathrm{Ti}$, and acetylacetonate negative ion, showed better color stabilization, compared to Co acetylacetonates, $\mathrm{Ni}, \mathrm{Mn}, \mathrm{Ti}, \mathrm{Fe}$ acetylacetonates, and the effects of $\mathrm{Fe}$ and $\mathrm{Ni}$ acetylacetonates on the prevention of the lignin photo-oxidation by the complex compound reaction with lignin was higher than any other metals (Zhu \& Evans, 2017). Besides, there have been other reports on reducing the photodecomposition of wood by applying tris-resorcinol triazine derivatives [1-isoctyloxy carbonyl ethylated 2,4,6,tris (2,4hydroxyphenyl)1,3,5,triazine], triazine UV absorbers and Benzotriazole UV absorbers to the film-forming coating (Schaller \& Rogez, 2007; Hayoz et al., 2003).

Since film-forming coating forms film on the surface of wood, it has considerably effected on protecting wood itself, but once the film is cracked or exfoliated, the film weathering is detected immediately, and it caused the high costs in weathered film removal and surface preparation paint for recoating (Shoubo, 2017). Furthermore, some studies have reported that it has lower inhibition microorganism, compared to the penetrating finishing coating, and dimensional stability effects, and thus, the surface protection would become more effective if paint is coated over after water repellent coating (Rowell, 2013; Singh \& Dawson, 2003).

Materials that form transparent film like varnish or lacquer are not for outdoor use; if used for exterior purposes, the wood surface would suffer from cracks or exfoliation less than two years after coating (Nejad \& Cooper, 2017). If these are still to be used in outdoors to keep the natural color of wood, transparent paints containing a UV stabilizer or fungicide can be adapted, but many studies have reported of the limited effects on the weathering prevention for the surface (Rowell, 2013; Singh \& Dawson, 2003). To prevent such pboblems, HALS (Hindered Amine Light Stabilizer) or chromic acid and other inorganic substances can be applied to the wood in advance before the transparent varnish or lacquer coating to improve weathering prevention effects (Evans et al., 2016; Rowell, 2013). Chang et al. (1998) reported that the preprocessing of Taiwania heartwood with HALS Tinuvin 292 and coating of a 
UV absorber, Tinuvin 1130, showed some synergy effects on the stabilization of color. Moreover, various techniques have been developed by researchers to improve the weathering prevention effect of transparent film-forming using UV absorbers and HALS as well as inorganic photo-stabilization additives, polyethylene glycol (PEG), polymerizable resins, and various aromatic compounds that allow for esterification of wood (Evans et al., 2016; Reinprecht \& Panek, 2015; Carola \& Mariaenrica, 2014; Forsthuber \& Grill, 2010; Pandey \& Chandrashekar, 2006; George et al., 2005, Schaller \& Rogez, 2007; Hayoz et al., 2003; Rogez, 2002; Chang \& Chou, 2000).

\subsection{Penetrating type coating}

Penetrating type coating is a finish that does not form film, but has the paint penetrate on the wood surface tissue, and it does not change the original surface property of the material. Compared to the film-forming type, it has lower wooden surface protection effect and shorter duration time for showing coating effects. However, if the penetrated paint layer is weathered, the weathering effect is not detected immediately, and it is easy to apply recoating (Shoubo, 2017). Materials used for the penetrating type coating are semitransparent stains including wood preservatives, water repellants, and dye, and other chemical materials penetrated into the structure of the wood surface (Nejad \& Cooper, 2017; Shoubo, 2017; Knaebe, 2013; Rowell, 2005). Stains are largely divided into transparent, semitransparent, and opaque stains. Transparent stains may include nano-size coloring agent, but generally, they do not contain coloring agent, requiring the addition of UV stabilizers or UV blockers to protect wood from UV (Nejad \& Cooper, 2017). However, semitransparent stains contain some coloring agent so that they protect the surface of wood from weathering, but they cannot completely prevent weathering by UV (Nejad \& Cooper, 2017;
Rowell, 2005). Rowell (2005) introduced that, in natural and artificial weathering tests on the Scots pine and Norway spruce coated with film-type paint and penetrating type semitransparent stains, the surface of wood applied with the semitransparent stains resulted in weathering and could not be protected from UV, as opposed to the paint with coloring agent. Some studies have shown that semitransparent oil-based stains with small amount of coloring agent showed the weathering resistance by two to five years, although the results differed by regions (Arnold et al., 1992; Stirling and Morris, 2013; Kiguchi et al., 1997). Semitransparent stains with high amount of coloring agent increases weathering protection effects from UV, but the wood's natural patterns and color is hidden, and thus, the amount of coloring agent is considered to be important (Nejad \& Cooper, 2017; Knaebe, 2013). Opaque stains with high amount of coloring agent can not only block UV almost completely, but also they do not show little cracking or exfoliation shown by the varnish or paint film. The durability of the penetrating type stains is dependent largely upon the factors of the amount of coloring agent, resin, preservatives, water repellants, and the amount of stains used for coating, and reports have indicated that the best result on preventing weathering was based on a stain system sufficiently combining all these factors (Rowell, 2013). It is reported that the use of penetrating type, water-repelling stains that contain water repellant and wood preservative or oil-based semitransparent stains on low-durable wood under highly moist environment, would offer highly water-repelling effects, resulting the effective weathering prevention (Knaebe, 2013). Particularly, hydrophobic oil-based water repellant or wax coating based on resin-based water repellant was shown to enhance the waterproof effects with over $90^{\circ}$ of the contact angle, and other studies have examined weathering prevention by using Polyvinylidene fluoride (PVDF) and other resins, UV stabilizers or antimicrobial agents (Landry 
et al., 2013; Landry \& Blanchet, 2012; Kiguchi et al., 1997).

\section{CHEMICAL MODIFICATIONS}

Besides the weathering prevention methods discussed above, many other methods have been proposed. Some scholars have conducted chemical modification studies on wood so as to reduce the hydrophilic properties of wood, and increase the dimensional stability by the change of moisture as well as the resistance to weathering. In other words, the chemical modifications based on methylation, acetylation or alkylation formed quinone, which blocks phenolic hydroxyl groups and improves the color stabilizations on the surface of wood by light (Rowell et al., 2009; Hill, 2006; Ohkoshi, 2002; Beckers et al., 1998). Acetylated wood with the weight increase by 10 to $20 \%$ tends to reduce yellowish photo-induced weathering, cracking or surface erosion (Rowell, 2013; Pandey \& Pitman, 2002; Evans et al., 2000a). Particularly, if the weight is increased by more than $20 \%$ due to acetylation, wood is protected from weathering, indicating that the acetylation level influences the weathering effect (Alfredsen et al., 2013). Ohkoshi et al. (2002) attempted to combine the acetylation process and polyethylene glycol methacrylation process to improve the acetylation wood's resistance to weathering and reported that it was able to reduce discoloring and surface cracking on wood. However, while acetylation has been reported to enhance relatively superior resistance to weathering compared to various other chemical processes, when wood is exposed to environments for a long time, acetylated wood surface is exfoliated due to removement of acetyl group by weathering (Gobakken \& Westin, 2008; Evans et al., 2000a). Furthermore, it has been reported that the acetate that was generated in the acetylation process remains on wood, promoting the oxidation of wood components, when exposed outdoor environments in particular, the acetylation would not greatly improve the resistance for weathering, and thus, further advanced research is required on this subject (Rowell, 2013; Imamura, 1993). In addition, there are other chemical modification methods of protecting wood from discoloring, cracking, or photo-degradation. The other reported methods are, the esterification of wood using succinic or proprionic anhydrides, phthalic anhydrides, aromatic vinyl ester, and vinyl benzoate, etc., by benzyl processing (Bhat et al., 2010; Pandey \& Chandrashekar, 2006; Evans et al., 2002), and penetration treatment of synthetic materials such as styrene and methylmethacrylate and other polymerizable monomers, phenol formaldehyde resin and melamine formaldehyde resin, and etc. (Hansmann et al., 2006; Sudiyani et al., 2001; Rapp \& Peek, 1999; Pittman et al., 1992).

\section{HEAT TREATMENT}

Heat treatment is one of the wood processing methods aiming to improve the dimensional stability and durability of wood by applying heat over $200^{\circ} \mathrm{C}$ for three to seven hours without oxygen and modifying its physical and chemical properties (Esteves \& Pereira, 2009). The reduction of $-\mathrm{OH}$ in wood due to the chemical modifications during the heat process leads to an increase of hydrophobicity, which results in the increase of the waterproofing effect on the surface of wood and offers excellent surface performance (Nejad et al., 2012; Petrissans et al., 2003). But there are several contradicting research results on the heat-treated wood's resistance to weathering. Huang et al. (2012) reported that when the heat-treated wood was exposed to the weather, the crystalline region of the cellulose was broken during the heat treatment process, and the hydrophilic group increased, including the increase of wetness of the surface. Ayadi et al. (2003) and Shi \& Jiang (2011) reported that, when exposed to outdoor for a short time, 
heat-treated wood would show less discoloring and surface erosion and more resistant to discoloring germs like A. pullulans, compared to unheated wood. Wolkenhauer et al. (2008) and Awoyemi et al. (2009) reported that there was no improvement on weathering prevention by heat treatments and some studies reported that coating performance decreased compared to unheated wood (Nejad et al., 2012; Petrič et al., 2007; Jämsä et al., 2000). Colors of the heat-treated ash wood and iroko wood changed to bright sliver as the duration of the natural weathering test increased, and heat-treated Scots pine changed to a darker color for the first 18 months, and to silver grey after about 24 months. Xing et al. (2015) found that the weathering resistance of heat-treated wood would improve in the initial period of the exposure to weather, but in the long run, its resistance to weathering was low. Furthermore, MOR of heat-treated wood after the natural weathering test decreased and infected with sapstain fungi (Tomak et al., 2014). Even though the studies on heat-treated wood reported that it had lower absorptiveness than preservative treated wood, but the heat-treated woods had an almost similar level of weathering deterioration, compared to unheated wood (Dubey et al., 2010; Nejad \& Cooper, 2013). Nejad et al. (2017) emphasized that heat-treated wood would require coating with stronger UV-resistant paint than the preservative treated wood.

\section{Conclusions}

A review of research trends on wood surface protection in exterior use obtained the following conclusions:

1. Inorganic compounds such as chrome and copper used as wood preservatives can protect wood from weathering.

2. Precoating with hydrophobic substances such as wax and oil, UV absorbers, and HALS (Hindered Amine Light Stabilizers) enhances weathering resistance on the surface of ACQ-treated wood.

3. Opaque coatings of paint/stains and semitransparent stains on the surface of preservative treated wood can increase synergy effects on prevention of weathering deterioration.

4. The need for repainting periodically for the protection of the preservative treated wood surface has also been suggested.

5. $\mathrm{ZnO}$ or $\mathrm{TiO}_{2}$ of fine particles, metal ions such as $\mathrm{Co}, \mathrm{Cr}, \mathrm{Fe}, \mathrm{Mn}, \mathrm{Ni}$ and $\mathrm{Ti}$, and UV absorbers such as tris-resorcinol triazine derivatives, triazine and benzotriazole were introduced as additives for preventing UV in the transparent coating on wood.

6. Chemical modification such as methylation, acetylation, or alkylations have increased the effect of preventing weathering with the increasing weight gain of chemical formulas.

7. In heat-treated wood, there were various contradictory reports on the resistance of weathering, and other reports prolcaimed the necessity of painting with UV resistance, which leads to the necessity of more advanced studies.

\section{ACKNOWLEDGMENT}

This research was supported by the research fund from Kookmin University (2015).

\section{REFERENCES}

Alfredsen, G., Flæte, P.O., Militz, H. 2013. Decay resistance of acetic anhydride modified wood: a review. International Wood Products Journal 4(3): 137-143.

Aloui, F., Ahajji, A., Irmouli, Y., George, B., Charrier, B., Merlin, A. 2007. Inorganic UV absorbers for the photostabilisation of wood-clearcoating systems: comparison with organic UV absorbers. Applied Surface Science 253(8): 3737-3745. 
Arnold, M., Feist, W.C., William R.S. 1992. Effect of weathering new wood on the subsequent performance of semitransparent stain. Forest Products Journal 42(3): 10-14.

Awoyemi, L., Cooper, P., Ung, T. 2009. In-treatment cooling during thermal modification of wood in soy oil medium: soy oil uptake, wettability, water uptake and swelling properties. European Journal of Wood and Wood Products 67(4): 465-470.

Ayadi, N., Lejeune, F., Charrier, F., Charrier, B., Merlin, A. 2003. Colour stability of heat-treated wood during artificial weathering. Holz alz Roh- und Werkstoff 61(3): 221-226.

Beckers, E.P.J., de Keijer, M., Militz, H., Stevens, M. 1998. Performance of finishes on wood that is chemically modified by acetylation. Journal of Coatings Technology 70(878): 59-67.

Bhat, I., Khalil, H.P.S.A., Awang, K.B., Bakare, I.O., Issam, A.M. 2010. Effect of weathering on physical, mechanical and morphological properties of chemically modified wood materials. Materials \& Design 31(9): 4363-4368.

Bull, D.C. 2001. The chemistry of chromated copper aarsenate ll, Preseervative-wood interactions. Wood Science and Technology 34(6): 459-466.

Carola, E.C., Mariaenrica, F. 2014. Novel UV-cured nanocomposite used for the protection of walnut wood artworks. Wood Research 59: 229-244.

Chang, S.T., Hon, D.N.S., Feist, W.C. 1982. Photodegradation and Photoprotection of wood surfaces. Wood \& Fiber Science 14(2): 104-117.

Chang, S.T., Chou, P.L. 2000. Photodiscoloration inhibition of wood coated with UV-curable acrylic clear coatings and its elucidation. Polymer Degradation and Stability 69: 355-360.

Chang, S.T., Wand, S.Y., Su, Y.C. 1998. Retention of red color in Taiwania (Taiwania cryptomeriodesHay.) haertwood. Holzforschung 52(1): 13-17.

Christy, A.G., Senden, T.J., Evans, P.D. 2005.
Automated measurement of checks at wood surfaces. Measurement 37(2): 109-118.

Cornfield, A., Hale, M., Fellis, G. 1994. A comparison of analytical and visual techniques used for assessment of weathering properties of chromium and copper azole treated timber, International Research Group on Wood preservation, IRG/WP/ 94-20023.

Cristea, M.V., Riedl, B., Blanchet, P. 2010. Enhancing the performance of exterior waterborne coatings for wood by inorganic nanosized UV absorbers. Progress in Organic Coatings 69(4): 432-441.

Cui, F., Zahora, A.R., 2000. Effect of Water repellent additive on the performance of ACQ treated decks, International Research Group on Wood Preservation IRG/WP 00-40168.

Dubey, M.K., Pang, S., Walker, J. 2010. Color and dimensional stability of oil heat-treated radiata pinewood after accelerated UV weathering. Forest Products Journal 60(5): 453-459.

Ekstedt, J. 2002. Influence of coating additives on water vapour absorption and desorption in Norway spruce. Holzforschung 56(6): 663-668.

Esteves, B.M., Pereira H.M. 2009. Wood modification by heat treatment: A review. BioResources 4(1): 370-404.

Evans, P.D., Michell, A.J., Schmalzl, K.J. 1992. Studies of the degradation and protection of wood surfaces. Wood Science \& Technology 26(2): 151-163.

Evans, P.D., Pirie, J.D.R., Cunningham, R.B., Donnelly, C.F., Schmalzl, K.J. 1994. A Quantitative weathering study of wood surfaces modified by cchromium VI and iron III compounds. Part 2. Image analysis of cell wall pet micro-checking. Holzforschung 48(4): 331-336.

Evans, P.D., Schmalzl, K.J. 1989. A Quantitative weathering study of wood surfaces modigied by cchromium VI and iron III compounds. Part 1. Loss in zero-span tensile strength and weight of thin 
wood veneers. Holzforschung 43(5): 289-292.

Evans, P.D., Owens, N.L., Schmid, S., Webster, R.D. 2002. Weathering and photostability of benzoylated wood. Polymer Degradation and Stability 76: 291-303.

Evans, P.D., Vollmer, S., Kim, J.D.W., Chan, G., Kraushaar Gibson, S. 2016. Improving the performance of clear coatings on wood through the aggregation of marginal gains. Coatings 6(4): 66 .

Evans, P.D., Wallis, A.F.A., Owen, N.L. 2000a. Weathering of chemically modified wood surfacesNatural weathering of Scots pine acetylated to different weight gains. Wood Science \& Technology 34(2): 151-165.

Evans, P.D., Donnelly, C.F., Cunningham, R.B. 2003, Checking of CCA-treated radiata pine decking timber exposed to natural weathering. Forest Products Journal 53(4): 66-71.

Evans, P.D., Wingate-Hill, R., Cunningham, R.B. 2009. Wax and oil emulsion additives:How effective are they at improving the performance of preservativetreated wood. Forest Products Journal 59(1/2): 66-70.

Feist, W.C., Ross, A.S. 1995. Performance and durability of finishes on previously coated CCAtreated wood. Forest Products Journal 45(9): 29.

Feist, W., Williams, R.S., 1991. Weathering durability of chromium-treated southern pine. Forest Products Journal 41(1): 8-14.

Forsthuber, B., Grill, G. 2010. The effects of HALS in the prevention of photodegradation of acrylic clear topcoats and wooden surfaces. Polymer Degradation and Stability 95: 746-755.

George, B., Suttie, E., Merlin, A., Deglise, X. 2005. Photodegradation and photostabilisation of woodThe state of the art. Polymer Degradation and Stability 88(2): 268-274.

Gobakken, L.R., Westin, M. 2008. Surface mould growth on five modified wood substrates coated with three different coating systems when exposed outdoors. International Biodeterioration \& Biodegradation 62(4): 397-402.

Grelier, S., Castellan A., Kamdem D.P. 2000. Photoprotection of copper-amine-treated pine. Wood and Fiber Science 32(2): 196-202.

Grill, G., Tscherne, F., Spitaler, I., Forsthuber, B. 2014. Comparison of wood coating durability in natural weathering and artificial weathering using fluorescent UV-lamps and water. European Journal of Wood and Wood Products 72(3): 367-376.

Hansmann, C., Deka, M., Wimmer, R., Gindl, W. 2006. Artificial weathering of wood surfaces modified by melamine formaldehyde resins. Holz als Roh-und Werkstoff 64(3): 198-203.

Hayoz, P., Peter, W., Rogez, D. 2003. A new innovative stabilization method for the protection of natural wood. Progress in Organic Coatings 48: 297-309.

Hill, C.A.S. 2006. Wood modification, Chemical, Thermal and other processes. John Wiley \& Sons. Chichester

Hon, D.N.S., Chang, S.T. 1985. Photoprotection of wood surfaces by woo-ion complexes. Wood \& Fiber Science 17(1): 92-100.

Hon, D.N.S. 2010. Weathering and photochemistry of wood. In Wood and cellulosic chemistry, 2 ed.; Hon, D. N.-S.; Shiraishi, N., Eds. 513-, The CRC Press, Taylor \& Francis Group

Huang, X., Kocaefe, D., Kocaefe, Y. Boluk, Y., Pichette, A. 2012. Changes in wettability of heat-treated wood due to artificial weathering. Wood Science and Technology 46(6); 1215-1237

mamura, Y. 1993.Morphological Changes in Acetylated Wood Exposed to Weathering. Wood research : bulletin of the Wood Research Institute Kyoto University 79: 54-61.

Isaji, S. 2016. Weathering durability and service life prediction of coated wood in cold and snowy region. Mokuzaihozon 42(2): 56-61. 
Ishikawa, A., Kataoka, Y., Mastunaga, M., Kobayashi, T., Kobayashi, M., Mastunaga, H., Kawamoto, S., Kiguchi, M., Yamamoto, K. 2017. Weatherability of wood preservative semi-transparent coatings (IV)

- Effects of re-finishing on service-life extension-, Mokuzaihozon(Wood Protection) 43(2): 80-89.

Jämsä, S., Ahola, P., Viitaniemi, P. 2000. Long-term natural weathering of coated ThermoWood. Pigment \& Resin Technology 29(2): 68-74.

Kataoka, Y., Ishikawa, A., Kobayashi, M., Matsunaga, M., Matsunaga, H., Kiguchi, M. 2015. Weatherability of sugi (Crytomeria japonica D.Don) sound brriers - Enhanced performance of coatings applied on preservative-treated wood. Mokuzaihozon 41(2): 62-70.

Kataoka, Y., Yamamoto, K., Kawamoto, S., Kobayashi, M., Kiguchi, M. 2011a. Weatherability of waterborne wood preservative semi-transparent coatings(II) -Performance of coatings after re-finishing without removing old finish. Mokuzaihozon 37(2): 64-73.

Kataoka, Y., Yamamoto, K., Kawamoto, S., Kobayashi, M., Kiguchi, M. 2011b. Weatherability of waterborne wood preservative semi-transparent coatings (III) - The effects of sandinf process prior to re-finishing. Mokuzaihozon 37(6): 264-272.

Khedkar, S.V., Thorat, P.V., Pande, P.S., \& Gopalani, R.P., 2017. Study of separation of pigments in paints for development of multicolor paint. Journal for Research, 3(Issue 04), 9-13.

Kiguchi, M., Kataoka, Y., Doi, S., Mori, M., Hasegawa, M., Morita, S., Kinjo, M., Kadekaru, Y., Imamura, Y. 1997. Improvement of weather resistance of fi lm-forming type clear finishes by pre-treatment with PEG and influence of exposure test sites. Mokuzai Hozon 22: 10-17.

Kiguchi, M., Suzuki, M., Kinoshita, T., Kawamura, J. 1997. Evaluation of exterior pigmented stains by a new criterion of refinishing. Mokuzai Gakkaishi 52: 612-617.
Kim, K.H., Lee, D.H., Lee, M.J., 2003a. Effect of Accelerated Weathering on the Leaching of Copper from Preservative Treated Wood. Journal of the Korean Wood Science and Technology 31(4): 38-43

Kim, K.H., Lee, D.H., Lee, M.J., 2003b. Evaluation of Weathering Durability of Waterborne Preservative Treated Wood by Accelerated Weathering. Journal of the Korean Wood Science and Technology 31(4): 44-49.

Kim, Y.S. 2017. Current Researches on The Weathering of Wood. Journal of the Korean Wood Science and Technology 45(5): 483-494.

Kim, Y.S., Cha, M.Y., Jeong, W.Y., Lee, K.H., Bae, H.J. 2009. Chemical and Morphological Change and Discoloration of Cedar Wood Stored Indoor. Journal of the Korean Wood Science and Technology 37(6): 566-577.

Kim, Y.S., Kim, G.H., Kim, Y.S., 2004. Wood preservation science, Publishing department of Cheonnam National University pp.160.

Kim, Y.S., Shin, H.C., Yoon, S.M., Park, S.H., Kim, S.D., Park M.K. 2017. Research on the characteristics of deteriorated woods by natural and accelerated weathering, A Report on the Consignment Research Projects of the National Institute of Forest Science, National Institute of Forest Science.

Knaebe, M. 2013. Finishline, Paint, stain, varnish, or preservative?, USDA Forest Service/Forest Products Laboratory, www.fpl.fs.fed.us

Korea Forest Service, Regulation 2016-2, Forest Carbon Offset Operating Standard for Social Contribution.

Landry, V., Blanchet, P. 2012. Weathering resistance of opaque PVDF-acrylic coatings applied on wood substrates. Progress in Organic Coatings 75(4): 494-501.

Landry, V., Blanchet, P., Zotig, L., Martel, T. 2013. Performance of exterior semitransparent PVDF- 
acrylic coatings. Journal of Coatings Technology and Research 10(1): 37-46.

Liu, C., Ahniyaz, A., Evans, P.D. 2010. Preliminary observations of the phothostabilization of wood surfaces with cerium oxide nanoparticles, Inernational Research Group on Wood Protection DocIRG/WP 10-40504.

Liu, R., Ruddick, J.N.R., Jin, L. 1994. The influence of copper(II) chemicals on the weathering or treated wood, Part 1 ACQ treatment of wood on weathering, International Research Group on Wood Preservation, IRG/WP 94-30040.

Murakami, K., Matsuda, H. 1990. Oligoesterified woods based on anhydride and epoxide VIII. Resistances of oligoesterified woods against weathering and biodeterioration. Mokuzai Gakkaishi 36(7): 538544.

Natale, M.F., Vidal, J.M. 2017. Evaluation of coating applied in treated wood: experiences in Brazil, In: Proceedings ofInternational Research Group on Wood Protection IRG/WP 17-40814.

Nejad, M. 2015. How to Increase the Lifespan of Exterior Wood Coatings, In: Proceedings ofInternational Research Group on Wood Protection IRG/WP 15-40700.

Nejad, M., Cooper, P. 2013. Performance characterization of coatings on treated-wood, Progress in Color, Colornats and Coatings pp.61-65.

Nejad, M., Cooper, P. 2010. Coatings to reduce wood preservative leaching. Environmental Science and Technology 44(16): 6162-6166.

Nejad, M., Cooper, P. 2011. Exterior wood coatings. Part-1: Performance of semitransparent stains on preservative-treated wood. Journal of Coatings Technology Research 8(4): 449-458.

Nejad, M., Cooper, P. 2017. Exterior wood coatings, In Wood in Civil Engineering, InTech.

Nejad, M., Dadbin, M., Cooper, P. 2017. studying weathering performance of coatings on thermally modified wood, In: Proceedings ofInternational Research Group on Wood Protection IRG/WP 17-40805.

Nejad, M., Shafaghi, R., Ali, H., Cooper, P. 2012. Coating performance on oil-heat-treated wood for flooring. BioResources 8(2): 1881-1892.

Ohkoshi, M. 2002. FTIR-PAS study of light-induced changes in the surface of acetylated or polyethylene glycol-impregnated wood. Journal of wood science 48(5): 394-401.

Ozgenc, O., Hiziroglu, S., Yildiz, U.C. 2012. Weathering properties of wood species treated with different coating applications. BioResources 7(4): 4875-4888.

Pandey, K.K., Pitman, A.J. 2002. Weathering characteristics of modified rubberwood(Hevea brasiliensis). J. Applied Polymer Science 85(3): 622-631.

Pandey, K.K., Chandrashekar, N. 2006. Photostability of wood surfaces esterified by benzoyl chloride. Journal of Applied Polymer Science 99: 2367-2374.

Park, C.H., Kim, H.J. 2013. Combustion behavior and weathering characteristic of sodium silicate coated wood. Journal of the Korean Wood Science and Technology pp.162-163.

Petrič, M., Knehtl, B., Krause, A., Militz, H., Pavlič, M., Pétrissans, M., Rapp, A., Tomažič, M., Welzbacher, C., Gérardin, P. 2007. Wettability of waterborne coatings on chemically and thermally modified pine wood. Journal of Coatings Technology Research 4(2): 203-206.

Petrissans, M., Gerardin, P., Serraj, M. 2003. Wettability of heat-treated wood. Holzforschung 57(3): 301307.

Pinnell, S.R., Fairhurst, D., Gillies, R., Mitchnick, M.A., Kollias, N. 2000. Microfine zinc oxide is a superior sunscreen ingredient to microfine titanium dioxide. Dermatologic surgery 26(4): 309-314.

Pittman, C.U., Kim, M.G., Nicholas, D.D., Wang, L.C., Kabir, F.R.A., Schultz, T. P., Ingram, L.I. 1992. 
Wood enhancement treatments. 1. Impregnation of southern yellow pine with melamine-formaldehyde and melamine-ammeline-formaldehyde resins. Holzforschung 46(5): 395-401.

Pizzi, A. 1980. Wood waterproofing and lignin crosslinking by means of chromium trioxide. guaiacyl units complexes. Journal of Applied Polymer Science 25(11): 2547-2553.

Qi, Y., Febrianto, F., Hwang, W.J., Hidayat, W., Jang, J.H., Park, S. W., Kim, N. H. 2016. Color Change of Major Wood Species Planted in Indonesia by Ultraviolet Radiation. Journal of the Korean Wood Science and Technology 44(1): 9-18.

Rapp, A.O., Peek, R.D. 1999. Melamine resin treated as well as varnish coated and untreated solid wood during two years of natural weathering. Holz als Roh-und Werkstoff 57(5): 331-339.

Reinprecht, L., Pánek, M. 2015. Effects of wood roughness, light pigments, and water repellent on the color stability of painted spruce subjected to natural and accelerated weathering. BioResources 10(4): 7203-7219.

Rogez, D. 2002. Color stabilization of wood and durability improvement of wood coaings: A new UV lightprotection concept for indoor and ortdoor applications. Paint \& Coatings Industry 18(3): 56-65.

Rowell, R. 2005. Handbook of Wood Chemistry and Wood Composites. CRC Press, Boca Raton, pp. 139-185.

Rowell, R.M. 2013. Handbook of wood chemistry and wood composites 2ndedtion, pp. 151-252.

Rowell, R.M., Ibach, R.E., McSweeny, J., Nilsson, T. 2009. Understanding decay resistance, dimensional stability and strength changes in heat-treated and acetylated wood. Wood material science and engineering 4(1-2): 14-22.

Salla, J., Pandey, K.K., Srinivas, K. 2012. Improvement of UV resistance of wood surfaces by using $\mathrm{ZnO}$ nanoparticles. Polymer Degradation and Stability 97(4): 592-596.

Satas, D., Tracton, A.A. 2001. Coatings Technology Handbook, New York: Marcel Dekker. 902.

Schaller, C., Rogez, D. 2007. New approaches in wood coating stabilization. Journal of Coatings Technology and Research 4(4): 401-409.

Schauwecker, C., Preston, A., Morrell, J.J. 2009. A look at the weathering performance of solid wood decking materials. Journal of Coatings Technology 6(9): 32-38.

Sharrock, R.F. 1990. A European approach to UV protection with a novel pigment. Journal of Coatings Technology 62(789): 125-130.

Shi, Q., Jiang, J.H. 2011. Color stability of heat-treated okan sapwood during artificial weathering. In Advanced Materials Research (Vol. 197), pp. 13-16. Trans Tech Publications.

Shin, H.C., Hwang, W.J., Yoon, S.M., Kim, Y.S. 2018. Changes in physical and chemical characteristics of commercial woods in Korea market exposed to accelerated weathering. Journal of the Korean Wood Science and Technology.

Shoubo, N. 2017. "Maintenance of exterior wood", In the report of open symposium on the woodysm of city and use of preservative treated wood in the 33rdannual conference of Japan Wood Protection Association. Mokuzaihozon 43(5): 290-293.

Singh, A.P., Dawson, B.S. 2003. The mechanism of failure of clear coated wooden boards as revealed by microscopy. International Association Wood Anatomists Journal 24(1): 1-11.

Sivrikaya, H., Can, A., Tümen, I., Aydemir, D. 2017. Weathering performance of wood treated with copper azole and woter repellents. Wood Research 62(3): 437-450.

Stirling, R., Landry, V. 2016. Colorant Treatments to Enhance the Weathering Resistance of Western Red cedar, In: Proceedings ofInternational Research 
Group on Wood Protection IRG/WP 16-40737.

Stirling, R., Morris, P.I. 2013. Performance of coatings on wood treated with carbon-based preservatives, In: Proceedings ofInternational Research Group on Wood Protection IRG/WP 13-40638.

Sudiyani, Y., Ryu, J.Y., Hattori, N., Imamura, Y. 2001. Phenolic resin treatment of wood for improving weathering properties. In: Imamura, Y. (Ed.), High-performance Utilization of Wood for Outdoor Uses,World Research Institute, Kyoto University, Kyoto. Japan pp. 85-96.

Tanczos, I., Schmidt, H. 2002. Quantam process-new sulfur-free delignification. Journal of Wood Chemistry and Technology 22(4): 219-233.

Temiz, A., Yildiz, U.C., Aydin, I., Eikenes, M., Alfredsen, G., Colakoglu, G. 2005: Surface roughness and color characteristics of wood treated with preservatives after accelerated weathering test. Applied Surface Science 250(1-4): 35-42.

The Korea wood newspaper, 2017. The Present Status of Modern Wooden Architecture in Korea, No. 554

Tomak, E.D., Ustaomer, D., Yildiz, S., Pesman, E. 2014. Changes in surface and mechanical properties of heat-treated wood during natural weathering. Measurement 53: 30-39.

Turkoglu, T., Baysal, E., Toker, H. 2015. The effects of natural weathering on color stability of impregnated and varnished wood materials, Advances in Materials Science and Engineering.

Weichelt, F., Emmler, R., Flyunt, R., Beyer, E.,
Buchmeiser, M.R., Beyer, M. 2010. ZnO-Based UV Nanocomposites for Wood Coatings in Outdoor Applications. Macromolecular Materials \& Engineering 295(2): 130-136.

Williams, R.S., Sotos, P., Feist, W.C. 1999. Evaluation of several finishes on severely weathered wood. Journal of Coatings Technology 71(895): 97-102. Wolkenhauer, A., Wolkenhauer, A., Avramidis, G., Militz, H., Viöl, W. 2008. Plasma treatment of heat treated beech wood-investigation on surface free energy. Holzforschung 62(4): 472-474.

Xing, D., Wang, S., Li, J. 2015. Effect of Artificial Weathering on the Properties of Industrial-Scale thermally Modified Wood. BioResources 10(4), 8238-8252

Yu, Y., Jiang, Z., Wang, G., Song, Y. 2010. Growth of $\mathrm{ZnO}$ nanofilms on wood with improved photostability. Holzforschung 64(3): 385-390.

Yuner, Z., Evans, P.D. 2017. Surface Protection of Wood with Metal Acetylacetonates, In: Proceedings of International Research Group on Wood Protection IRG/WP 17-40802.

Zahora, A.R. 2000. Long-term performance of a "wax' type additive for use with water-borne pressure preservative treatments, International Research Group on Wood Preservation IRG/WP 00-40159.

Zhang, J., Kamdem, D.P., Temiz, A. 2009. Weathering of copper-amine treated wood. Applied Surface Science 256(3): 842-846. 
Yeong-Suk Kim

\title{
APPENDIX
}

\author{
(Korean Version)
}

\section{목재의 기상열화 방지에 관한 최근의 연구 동향}

요약 : 본 총설에서는 외부에 사용되는 목재를 풍화인자로부터 보호하기 위해 실행되고 있는 최근의 연구동향에 대해 조사 분석하였다. 주요 기상열화 인자로부터 목재의 표면 보호를 위한 연구 동향에 대하여 조사한 결과 다음과 같은 결론을 얻었다. 목재보존제로 사용된 크롬, 구리 등의 무기화합물이 목재를 기상열화로부터 보호할 수 있는 것으로 보고되었다. 또한 ACQ처리 목재의 표면에 wax나 oil같은 소수성물질과 UV 흡수제, HALS(Hindered Amine Light Stabilizers) 등을 방부목재 표면에 precoating하면 기상열화 저항성을 강화할 수 있다고 보고되었다. 또한 방부목재 표면에 불투명 도막형성의 페인트/스테인 및 반투명스테인등이 기상열화방지에 대한 시너지 효과가 높힐수 있다는 보고들이 다수 있었다. 또한 방부목재의 표면보호를 위한 재도장 처리의 필요성이 시사되었다. 투명성의 도막에 UV방지를 위한 첨가물로서 미세입자의 $\mathrm{ZnO}$ 또는 $\mathrm{TiO} \mathrm{C}_{2}, \mathrm{Co}, \mathrm{Cr}$, $\mathrm{Fe}, \mathrm{Mn}, \mathrm{Ni}$ 과 $\mathrm{Ti}$ 등의 금속이온, Tris-resorcinol triazine derivatives, triazine 및 Benzotriazole과 같은 UV흡수제 등이 소개되었 다. Methylation, acetylation 또는 alkylation 등과 같이 화학적으로 개질된 경우에는 이로 인한 중량증가가 높은 경우 기상열화 방지효과가 상승된다는 연구들이 소개되었다, 열처리목재의 기상열화 저항성에 대해서는 여러 가지 상반되는 연구보고 들이 있었고, UV저항성을 지닌 도장의 필요성이 강조된 보고가 있어 보다 심도 있는 연구의 필요성이 시사되었다.

\section{1. 서언}

최근 『탄소흡수원 유지 및 증진에 관한 법률』제 27 조 및 동 법 시행령 제24조 기반의『사회공헌형 산림탄소 상쇄 운영표준』을 제정하고, 목제품 이용이 산림탄소상쇄 사업유형으로 제시하는 등 향후 목재 사용이 더욱 증가될 것으로 예측되고 있다(Korea Forest Service, Rregulation 2016-2). 또한 건축시장의 불경기에도 불구하고 2016년 목조주택 착공동수가 전년 대비 12\%정도 상승하는 등 지속적으로 높은 성장률을 보였다(The Korea wood newspaper, 2017). 이와 같은 상황에서, 2017년 전국에 분포하 는 5 25년 정도 경과된 목조주택, 23건을 대상으로 외장목재에 발생한 기상열화에 대해 조사한 결과, 조사대상 대부분의 외장목 재에서 다양한 기상열화가 발생하였음을 보고하였다(Kim et al., 2017). 기상열화 현상 중에서 색상변화가 가장 많았고, 표면의 갈라짐이나 할열 등의 결점이 많았으며, 심한 경우에는 표면할열을 통한 내부부후까지 진행된 경우도 발견되었다. 국내에서 주로 사용된 수종은 미송, SPF 및 뉴송과 같은 수입소나무재와 국내산 낙엽송 등이 주종이었는데, 인공촉진내후조작시험에서 이들 수종이 노출 후 30일정도의 경과시간에 색상변화 등 기상열화가 현저하게 발생함이 밝혀졌다(Shin et al., 2018). 기상열화 가 발생한 부재들은 로그하우스, 한옥 및 경골목구조 등 다양한 목조건축물에서 모두 발생되었고, 외기에 노출되는 목재사이딩, 창틀, 페시아보드 및 데크 등의 부재에서 주로 심한 기상열화가 나타났다. 또한 부재가 사용된 환경분석에서 부재의 위치가 남향뿐 아니라 그 외의 위치에서도 많은 기상열화 발생이 밝혀져 국내에서도 외부용 목재에 반드시 기상열화로부터 보호될 수 있는 처리가 중요하게 다루어져야 하는 상황이 시사되었다(Kim et al., 2017). 특히 목재의 기상열화에 관한 최근의 연구동향 (Kim, 2017)이나, 국내 환경에서의 기상열화에 대한 연구보고는 다수 있었으며 이들은 목재의 재색 및 성분 변화 등의 현상을 보고한 바 있다(Qi et al., 2016; Kim et al., 2009).

목재의 기상열화에 영향하는 환경적 인자에 관한 국내외 연구 동향에 의하면, UV와 IR, 가시광선과 같은 햇빛조사, 산소, 물, 열, 공해오염물질, 바람에 불려온 미세먼지, 미생물 등인 것으로 보고되었다(Kim, 2017; Qi et al., 2016; Rowell, 2013, Kim et al., 2003a, 2003b). 이들 인자들로 인해 발생하는 기상열화로부터 목재표면을 보호하기 위한 다양한 방지기술에 대한 연구들이 소개되었다(Nejad \& Cooper, 2017; Shoubo, 2017; Nejad, 2015; Rowell, 2013). 목재의 기상열화 방지 기술은 햇빛, 수분 및 미생물 등의 열화인자를 제어할 수 있는 작용기구로 표면보호를 추구하는 도장(coating), 목재보존제 및 수지의 주입처 리, 화학적 개질 처리 및 열처리 등이다(Nejad et al., 2017; Shoubo, 2017; Tomak et al., 2014; Rowell, 2013). 또한 색상변화 및 표면의 거칠음 같은 목재의 기상열화가 초기 수개월 2년 정도에 현저히 나타나는 경향이 있어 표면보호처리의 시점을 목재부재 설치 전후에 시행하는 방법이 일반적이고, 유지관리 차원에서 재처리에 관련된 연구들도 다수 보고되었다(Ishikawa et al., 2017; Kataoka et al., 2011a; Kataoka et al., 2011b).

본 총설에서는 문헌 자료를 통하여 근년에 주요 기상열화 인자로부터 목재의 표면 보호를 위한 각종 보존기술의 연구 동향에 
Current Researches on the Protection of Exterior Wood from Weathering

대하여 조사 분석해 보고자 하였다. 특히 목재보존제의 기상열화방지 특성, 목재보존제 구성성분의 용탈 방지 및 기상열화 저항성 증대를 위한 표면처리, 목재의 심미적 아름다움 유지 및 기상열화로부터 표면을 보호하기 위한 각종 첨가제와 도장기술, 화학적 개질 처리 및 열처리 등에 대해 주목하고 그에 대한 연구 동향을 검토하였다.

\section{2. 목재보존제 처리}

2.1. 목재보존제 처리의 기상열화 방지 특성

본래 목재보존제는 기상열화 방지보다는 부후균이나 목재해충에 의한 피해로부터 목재를 보호하여 목재 사용의 안전성제고 와 사용수명 증가를 목적으로 목재처리에 사용되는 약제이다(Kim et al., 2004). 목재의 기상열화는 주로 표면 최외층의 리그닌또는 추출물 등의 성분이 빛에 의한 광화학적 반응으로 발생되기 때문에 목재보존제 처리가 자외선과 수분으로 인한 기상열화로부터 목재를 완전히 보호할 수는 없는 경우가 많다. 그러나 주로 목재의 방부방충을 목적으로 처리되는 목재보존제 에 자외선과 수분 등의 기상열화 인자로부터 보호될 수 있는 화학성분을 함유한 경우에는 기상열화 방지효과를 나타내는 것으로 보고되고 있다. 본 항에서는 방부방충을 목적으로 사용되는 목재보존제가 기상열화의 효과를 나타내는 연구보고들에 대하여 소개한다.

목재보존제로 사용된 무기화합물들이 일부 목재표면을 자외선에 의한 열화로부터 보호할 수 있다고 소개되었다(Rowell, 2013). Feists와 Williams(1991)은 Southern pine에 CCA(Chromated Coper Arsenate)를 처리했을 때 기상열화 방지효과가 있고, $\mathrm{CCA}$ 를 가압처리한 경우, 표면에만 도포처리 했을 때보다 기상열화의 속도가 더 느리게 진행되었음을 보고하면서 약제의 흡수량이 많고, 침투깊이가 클 경우 기상열화 방지 효과가 더 크다는 것을 시사한 바 있다. 이 외에도 CCA처리목재가 기상열화 방지 효과를 나타내는 것에 대한 다양한 문헌들(Nejad \& Cooper, 2011; William \& Feist, 1985; Hon \& Chang, 1985; Evans et al., 1992,)이 있는데, CCA에 의한 주요 기상열화 방지 역할이 구성성분 중 무기물 성분이 목재 성분의 리그닌과 반응하여 물에 불용의 착화합물(chromate ester)을 형성함으로서 흡수성이 감소되어 소수성을 증가시키고, 자외선흡수를 저해하는 것으 로 보고되었다(Bull, 2001; Evans and Schmalzl, 1989, Evans et al., 1994; Pizzi, 1980; Chang et al., 1982). 특히 크롬을 함유한 CCA 처리 목재가 ACQ(Alkaline Copper Quat.) 또는 CuAz(Copper Azole) 로 처리된 목재에 비해서 물에 대한 방수성이 우수하다고 평가했고 이로 인해 CCA 처리목재의 기상열화 발생이 ACQ 또는 CuAz처리재에 비해 적게 나타날 수 있음이 시사된 바 있다(Nejad \& Cooper, 2011). 국내에서도 CCA, ACQ 및 CuAz과 같은 수용성 목재보존제로 처리된 방부목재에서 리그닌 분해가 무처리에 비해 상대적으로 적었고, 기상열화에 대한 저항성도 크게 나타났다는 연구보고가 있다 (Kim et al., 2003a, 2003b)

Archer \& Preston(2006)은 구리계 목재보존제에서 구리성분에 의한 자외선과 수분에 의한 기상열화 지연효과를 소개하였고, 타 연구자들에 의한 보고에서도 ACQ, CuAz 및 구리-ehtanolamine의 경우, 구리-amine착화합물 또는 산화구리가 자외선에 의한 리그닌 등의 광산화 저해 가능성이 있어서, 무처리에 비해서 기상열화 방지기능이 높음을 보고하였다(Shoubo, 2017; Nejad, 2015; Zhang et al., 2009; Timiz et al., 2005; Grelier et al., 2000; Cornfield et al., 1994; Liu et al., 1994). 그러나 국내시장에서 주요 목재보존제로 공급되는 ACQ는 구리성분과 함께 Alkylammonium compounds를 포함하는데 이 경우 Alkyl ammonium화합 물로 인한 친수성이 목재를 팽윤시켜 수분의 침투성이 커지기 때문에 목재표면에 자외선 침투깊이가 증가되는 특성을 지닌다 (Nejad \& Cooper, 2011) 이로 인해 빛에 의한 리그닌 등의 광산화반응이 촉진되어 기상열화 방지효과가 약화될 수 있는 것으로 나타났다. 따라서 기상열화에 대한 저항성 강화를 위해서는 또 다른 코팅처리 등의 조치가 요구되는 것으로 보고되었다(Tanczos \& Schmidt, 2002; Ekstedt, 2002; Worringham, 1994). 특히, Hon(2010)은 자외선과 목재성분의 반응으로 발생하는 자유라디칼이 수분으로 인해 증가됨을 보고하였고, 극성의 물이 목재표면에 더 깊이 침투하여 세포벽 팽윤을 유도하고, 결국 자외선 침투깊이를 증대시켜서 자유라디칼생성이 많아지고 목재표면의 기상열화가 보다 깊게 발생되는 원인이 됨을 보고하였다. 즉, 목재표면을 기상열화로부터 보호하기 위해서는 자외선과 목재 표면의 수분이 동시에 제어되어야 함을 강조하였다.

\section{2. 목재보존제 처리 목재에 도장처리}

$\mathrm{ACQ}$ 처리목재의 친수성을 제한하기 위한 다양한 연구보고들이 있는데, 보존처리 후, wax나 oil같은 소수성첨가제를 사 용하여 목재표면에 방수성을 부여하여 치수안정성이 향상시키는 방법이다(Evans et al., 2003; Evans et al., 2009; Zahora, 2000; Christy et al., 2005; Cui \& Zahora, 2000, Nejad \& Cooper, 2010). Nejad \& Cooper(2011)는 CCA, ACQ 및 CuAz 로 처리한 방부목재 표면에 다양한 도료를 도포하여 자연내후성시험을 3년간 실시하고, 흡수성, 색상변화, 표면할열 등의 항목에 대해 조사한 결과, 흡수성은 ACQ 및 CuAz처리재가 CCA처리재보다 높게 나타났고, CCA처리재에서는 유성도료 
가 수성에 비해 방수성이 좋았으나, ACQ 및 CuAz처리재에서는 유성 및 수성도료 간 유의적 차이는 보이지 않았다고 보고 하였다. 동 연구에서 CCA, ACQ 및 CuAz처리재는 무처리에 비해 색상변화가 적었으나 표면할열은 무처리재와 처리재간 에 유의적 차이가 없었고, 방부목재에 표면도장을 하면 표면할열 발생을 $30 ~ 40 \%$ 정도 감소시켜 표면 할열로 인한 기상열화 가능성이 감소했음을 보고하였다. Sivrikaya et al.(2017)은 CuAz로 처리된 방부목재 표면에 반투명도료를 처리했을 때 기상열화방지에 대한 시너지 효과가 높은 것으로 보고하였다. Kataoka et al.(2015)도 일본 삼나무에 $\mathrm{CuAz}$ 및 DDAC(Dimethyl Dodecyl Ammonium Chloride)로 처리하고, 그 표면에 각종의 수성 또는 유성도료로 도장한 후 108개월 간 일본 이바라키켄 츠쿠바시에서 실시한 자연내후성 시험에서 $\mathrm{CuAz}$ 처리재에 반투명도료로 도장했을 때 10 년정도의 건전 한 표면성을 유지할 수 있을 정도로 양호한 기상열화방지 효력이 있음을 보고한 바 있다. 그러나 western redcedar 의 기상 열화 방지를 위해 착색제도장을 실시한 연구에서는 색상변화 감소 효과는 있었으나 전형적인 미생물에 의한 기상열화 현상 인 검은색반점의 열화에는 효과가 없었다고 보고하였다(Stirling \& Landry, 2016). Southern pine과 Hemfir에 CCA약제로 처리된 방부목재 표면에 다양한 도료를 사용하여 표면처리한 시험결과에서 기상열화에 대해 가장 효과가 있었던 것은 완전 히 색소로 불투명하게 착색시킨 도막형성의 페인트/스테인 및 반투명스테인이었다는 결과를 보고하면서 외부에 사용되는 방부목재에 적절한 도장처리는 필수적임을 언급하였다(Feist \& Ross, 1995). 특히 Ozgenc et al.(2012)은 마이크로수준으로 미립자화한 구리계보존제를 처리한 목재 표면에 UV흡수제를 도포했을 때 소나무에서 그 효과가 좋았으나 활엽수인 너도밤 나무에서는 색상안정성과 코팅 침투가 방부처리재와 무처리간에 차이가 별로 없었음을 보고해 수종 간 기상열화 방지효과 가 다름을 시사하였다. 또한 Natale \& Vidal(2017)은 상용의 수용성 및 유용성 IPBC와 Cypermethrin, CCB(Copper Chromated Boron) 등으로 처리된 방부목재 표면에 유성바니시 및 페인트 도장을 실시하고 브라질 Luiz Antonio에서 8개월 간 자연내후성시험을 실시한 결과, 모든 데크 시험편에서 $90 \%$ 이상의 밝기변화 및 표면할열이 발생했고, CCB처리재에서 유일하게 변색방지와 표면 열화가 적었다고 보고하여 역시 무기물이 함유된 보존제가 기상열화 방지효과가 있음이 시사되 었다. 구리·붕소기반의 신규 보존제로서 Tanalith-E, Adolit-KDS 및 CCA를 oriental beech 및 scots pine에 주입처리하고 표면에 합성바니시와 폴리우레탄바니시를 도장처리하여 6개월간 자연내후조작을 실시한 결과에서도 무처리에 비해서 전체 적으로 색상변화가 낮았고, 그 중에서 Tanalith-E로 처리하고 폴리우레탄바니시 도장이 효과가 좋았다고 보고하였다 (Turkoglu et al., 2015). 이상에 서술된 바와 같이 목재보존제 중에 구리나 크롬과 같은 함유성분이 있는 경우에는 자외선이 나 수분에 의한 기상열화 방지효과가 일부 있으나, 금속물질을 포함하지 않은 유기 목재보존제들은 색소나 자외선에 대한 안정제 등의 물질을 첨가하지 않으면 기상열화 방지가 어렵다는 것이 시사되었다(Schauwecker et al., 2009). Stiring \& Morris(2013)등은 어떤 금속물질도 함유하지 탄소기반의 목재보존제로 처리된 목재에 기상열화저항성을 증대시키기 위해 유기자외선흡수제 및 자유라디칼 제어 기능의 HALS(Hindered Amine Light Stabilizers)를 사용한 프리코트 및 투명 또는 반투명도료로 마감 처리했을 때 기상열화 방지 효과가 있다고 보고하였다. 목재보존제로 처리된 목재의 표면 보호를 위하여 미국 산림청 임산물연구소에서는 그간의 연구결과에 기초하여 방부목재 표면에 2년마다 재도장처리로 표면 보호가 가능하 고, 재도장은 2가지 표면도장을 권장하였다. 첫 번째 도장은 유상에나멜로 얇게 도포하는 것이고, 그 후에 두 번째로 발수제 와 반투명 침투성 스테인을 도포할 것을 권장하고 있다(Knaebe, 2013).

\section{3. 표면도장에 의한 기상열화 방지}

표면도장(Surface coating)은 기상열화 인자로부터 목재표면을 보호하는데 매우 유용한 방법으로 소개되고 있다. 일본건축학 회에서 발행된 건축공사표준사양서 도장공사 JASS18에서는 외부용 목재도료를 착색마감용과 반투명마감도료로 구분하고, 반투명마감도료는 도막형성형(Film forming type)과 함침형(Penetrating finish type)으로 세분화 하고 있다(Shoubo, 2017). 착색마감도장은 염료에 의한 착색으로 불투명한 도막을 형성하기 때문에 바탕의 목재 문양이 보이지 않는 특성을 지닌다. 염료로 인해 자외선 차단효과가 커서 반투명성 마감도장에 비해 내후성이 우수한 특징을 지니나 도막아래층의 목재표면 점검이 어려워 기상열화 및 부후 등의 발생여부를 진단하기 어려운 점이 있는 것으로 보고되고 있다(Shobu, 2017; Knaebe, 2013; Rowell, 2013). 실제로 자외선 및 물 등 기상열화인자로부터 외부용 목재의 표면보호를 위해 적용되는 표면도장에는 반투명마감 도료 및 첨가제들과 관련된 연구보고들이 대부분이다(Rowell, 2005, 2013; Shoubo, 2017; Reinprecht \& Panck, 2015; Evans et al., 2016; Knaebe, 2013, Feist, 1983; Isaji, 2016; Park \& Kim, 2013; Landry et al., 2013; Landry \& Blanchet, 2012; Grull et al., 2014).

본 항에서는 목재의 기상열화 방지를 위해 연구된 도막형성형(Film forming type)과 함침형(Penetrating finish type)의 도장처 리 및 각종의 첨가제 효과 등과 관련된 다양한 연구동향에 대해 서술한다. 


\section{1. 도막형성의 표면도장}

도막 형성의 표면도장은 목재표면에 도막을 형성하여 표면을 보호하는 원리의 도장이다. 도막형성 도장에 사용되는 재료들은 모든 사양의 페인트(Paints), 바니시(Varsnishes), 락카(Lacquers) 등이 많이 사용된다(Nejad \& Cooper, 2017; Shoubo, 2017; Knaebe, 2013; Rowell, 2005; Feist, 1983).

도막형성 도장에 흔히 사용되는 페인트는 착색제를 함유하는 경우가 많은데 착색제는 색상을 나타내기도 하고 UV차폐기능을 가지기도 한다. 착색제 함량이 높을수록 자외선조사로부터 목재표면 보호기능이 커서 기상열화 방지기능이 높고 다양한 색상 선택이 가능한 장점을 가지는 것으로 알려져 있다(Nejad \& Cooper, 2017; Rowell, 2005; Satas \& Traction, 2001; Feist, 1983). 색소함량이 많아서 불투명한 페인트의 경우 외부에서 약 10 년까지 도막이 유지될 수 있고, 불투명한 도막보다 기상열화 방지효과 낮은 반투명 도장에서 도막의 두께를 두껍게 할수록 기상열화인자로부터 보호효과가 크다는 것을 보고하였다(Grull et al., 2014). 유성 또는 알키드 페인트는 기본적으로 오일에 무기물 색소가 함유된 현탁액이고, 라텍스 페인트는 수성으로 다양한 라텍스 수지와 무기물 색소의 현탁액이다(Feist, 1983, Bufkin \& Wildman, 1980). 특히 미국 USDA 산림청 임산물연구 소에서는 외부에 노출되는 목재 표면 보호용 페인트로서 아크릴계라텍스를 가장 우수한 재료로 추천하고 있다., 이 라텍스페인트 는 발수성으로 습기는 소통되는 다공성 도막을 가지는 유성페인트의 내구성을 능가하는 것으로 소개하고 있다(Knaebe, 2013; Evans et al., 1996, Feist, 1983). 아크릴계 도료에 Polyvinylidene fluoride(PVDF)를 첨가하여 기상열화로부터 다양한 침엽수 목재의 표면 보호 효과가 좋았다는 보고 등 다양한 고분자를 활용한 기상열화 방지 기술이 연구되기도 했다(Landry et al., 2013; Landry \& Blanchet, 2012). 아크릴계고분자는 햇빛에 저항성이 강하고 쉽게 기상열화되지 않는 특성으로 목재 표면보호에 상당히 효과가 좋고 효력의 지속성이 큰 장점이 있으나 redwood나 western redcedar 등의 목재에 함유된 수용성추출물이 라텍스페인트 도막으로 스며나올 수 있다. 이 같은 현상을 방지하기 위하여 초벌로 유성페인트 도포를 한 후 아크릴라텍스페인트 로 도포로 추출물이 도막에 스미는 것을 방지하여 약 15년 이상 표면 도장의 수명을 나타내었음을 소개한 보고들도 있다(Knaebe, 2013; Rowell, 2005; Williams et al., 1999).

페인트만으로 햇빛과 수분 등의 기상열화 인자들을 제어하지 못하는 경우, 도료에 무기물 등 목재표면의 기상열화방지에 도움이 되는 물질을 사용한다. 특히 철과 티타늄 및 산화아연과 같은 무기금속산화물은 UV를 흡수하거나 산란 효과로 목재표면 에 조사되는 UV 차단 효과를 꾀하는 첨가제로 이용될 수 있는데 이들 물질은 목재를 빛에 의한 열화로부터 보호효과가 크다고 보고되었다(Park \& Kim, 2013; Sharrock, 1990). 그러나 이들 무기화학물이 목재 자연의 색과 무늬를 유지하고자 하는 용도로 투명한 도료에 사용될 때 산화철 등의 물질로 인한 노란색 착색 또는 자연노출에서의 퇴색 등이 발생하여 사용이 제한되기도 한다(Aloui et al., 2007; Macleod et al., 1995; Singh \& Dawson, 2003 핸드북). 이러한 이유로 무기물입자의 투명성을 개선하여 투명한 도막형성을 가능하게 하기 위한 방안이 산화금속물 입자의 마이크로화 또는 나노화 가공이다. 미세한 무기물 입자를 사용함으로서 첨가물의 투명성이 좋아지고 도막에 기상열화 저항성이 커져서 유기계 UV흡수제나 HALS와 동등하거나 더 좋은 UV방지효과를 나타낸다는 연구결과들이 보고되었다(Auclair et al., 2011; Cristea et al., 2010; Liu et al., 2010; Yu et al., 2010; Weichelt et al., 2010; Pinnell, 2000; George et al., 2005). Ozgenc et al.(2012)는 Scots pine과 European beech에 마이크로수준으로 입자화한 $\mathrm{TiO}_{2}$ 와 Triazine UVA를 함유한 투명성 도장을 실시한 후, 인공촉진내후시험을 한 결과에서 마이크 로수준으로 입자화한 $\mathrm{TiO}_{2}$ 이 색상변화방지에 가장 효과가 좋았다고 보고하였다. $\mathrm{ZnO}$ 또는 $\mathrm{TiO}_{2}$ 를 나노수준으로 미립자화 하여 수성도료에 혼입하여 black spruce에 처리한 결과에서도 우수한 기상열화 방지효과가 있었다고 보고하였다(Salla et al., 2012; Cristea et al., 2010). 또한 $\mathrm{Co}, \mathrm{Cr}, \mathrm{Fe}, \mathrm{Mn}, \mathrm{Ni}$ 과 Ti 등의 금속이온과 acetylacetonate 음이온의 복합체인 Metal acetylacetonates를 사용한 결과, $\mathrm{Ni}, \mathrm{Mn}, \mathrm{Ti}, \mathrm{Fe}$ acetylacetonates가 Co acetylacetonates에 비해 색상안정성에 더 효과가 컸고, $\mathrm{Fe}$ 과 $\mathrm{Ni}$ acetylacetonates는 리그닌과의 착화합물화 반응에 의해 리그닌 광산화를 저지하는 효과가 타 금속에 비해 높았다고 보고하였다(Zhu \& Evans, 2017). 이 밖에도 도막형성형 투명코팅에 tris-resorcinol triazine derivatives[1-isoctyloxy carbonyl ethylated 2,4,6,tris(2,4-hydroxyphenyl)1,3,5,triazine], triazine UV흡수제 및 Benzotriazole UV흡수제를 적용해서 목재의 광분 해를 감소시키는 결과들이 보고된 바 있다(Schaller \& Rogez, 2007; Hayoz et al., 2003)

도막 형성형 표면도장은 목재표면에 도막을 형성하기 때문에 목재자체를 보호하는 효과가 크긴 하지만 일단 도막이 갈라지거 나 박리현상이 나타나면 도막열화가 바로 눈에 띄고 재도장을 위한 열화 도막제거와 하지처리에 시간이 소요되는 등 고비용의 단점이 있다고 보고된 바 있다(Shoubo, 2017). 또한 함침형 도장에 비해 부후와 치수안정효과가 낮아서 일단 발수제로 처리한 위에 페인트로 도포하면 표면보호기능이 더 효과적이라고 보고하였다(Rowell, 2013; 핸드북 Singh \& Dawson, 2003; Feist, 1990a; Feist, 1990b).

바니시와 락카와 같이 투명한 도막을 형성하는 물질은 외부용으로 사용되는 것이 아니어서 그대로 외부에 사용하면 도장 후 2년도 안되어서 목재표면에 갈라짐이나 벗겨지는 결함이 발생한다(Nejad \& Cooper, 2017). 그럼에도 불구하고 외부에서 
사용하는 목재의 자연색감을 유지하기 위해 사용하고자 할 때에는 UV 안정제나 항균성약제등이 함유된 투명 도료가 사용되기도 하지만 실제 표면의 열화 방지 효과는 제한적이라는 보고들이 많다(Macleod et al., 1995; Singh \& Dawson, 2003). 이 같은 현상을 방지하기 위하여 투명한 바니시나 락카를 도장하기 전에 HALS(Hindered Amine Light Stabilizer) 또는 크롬산 등 무기화합물을 목재에 전처리함으로서 기상열화 방지를 꾀하는 연구가 보고되기도 하였다(Evans et al., 2016; Rowell, 2013; Williams \& Feist, 1985). Chang et al.(1998)은 Taiwania 심재에 HALS Tinuvin292로 전처리하고, UV흡수제인 Tinuvin1130을 도포했을 때 목재의 색상안정에 시너지 효과가 있었다고 보고하였다. 이밖에도 UV흡수제 및 HALS는 물로, 무기물의 광안정화 첨가물, polyethylene glycol(PEG), 중합가능한 수지들, 목재의 ester화가 가능한 다양한 방향족화합물들을 활용하여 투명한 도막형성의 기상열화 방지효과를 증진시키는 많은 기술들이 여러 연구자들에 의해 보고되었다(Evans et al., 2016; Reinprecht \& Panek, 2015; Carola \& Mariaenrica, 2014; Kiguchi et al., 1997; Chang \& Chou, 2000; Forsthuber \& Grill, 2010; Pandey \& Chandrashekar, 2006; George et al., 2005, Schaller \& Rogez, 2007; Hayoz et al., 2003; Rogez, 2002)

\section{2. 함침형 도장}

함침형 도장은 목재표면에 도료가 침투하여 도막이 형성되지 않는 마감으로 소재가 가지는 고유의 표면성이 많이 변하지 않는 특징을 가진다. 도막 형성형에 비해 목재표면 보호효과가 낮으며 도장효과를 나타내는 기간도 짧지만, 침투된 도료층이 열화된 경우에 도막형성형과는 달리 열화가 바로 눈에 띄지 않고 재도장이 용이한 특징이 있다(Shoubo, 2017). 함침형의 표면도장에 사용되는 것은 목재보존제, 발수제 종류, 염료를 포함한 반투명스테인(Semitransparent stains), 기타 화학물질 등 목재표면의 조직에 침투되는 형태의 물질들을 포함한다(Nejad \& Cooper, 2017; Shoubo, 2017; Knaebe, 2013; Rowell, 2005; Feist, 1983). 스테인은 크게 투명성, 반투명성, 불투명한 색상 스테인으로 나뉘어진다. 투명성스테인은 나노크기의 색소가 함유되어 있기도 하지만 일반적으로 색소를 포함하지 않아서 UV로부터 목재 보호를 위해서는 UV안정제나 UV차단 제 등의 첨가가 필요하다(Nejad \& Cooper, 2017). 그러나 반투명성 스테인은 색소가 어느 정도 함유되어 있어서 목재표면을 기상열화로부터 보호하는 효과가 있으나 자외선에 의한 기상열화를 완전히 방지하기는 어렵다는 보고들이 있다(Nejad \& Cooper, 2017; Rowell, 2005, Feist, 1988). Turkulin et al.(1997)은 Scots pine과 Norway spruce에 도막형의 페인트와 함침형 의 반투명스테인을 도장하고 자연 및 인공내후성시험을 시행한 결과에서 반투명스테인의 경우에 색소를 함유한 페인트와 달리 목재표면에 기상열화가 발생하여 UV로부터 보호되지 못했다고 보고한 바 있다. 몇몇의 연구에서 색소함량이 작은 반투명의 유성스테인은 지역에 따라 다르긴 하나 약 2 5년정도의 기상열화저항성을 나타내었다(Arnold et al., 1992; Stirling and Morris, 2013; Kiguchi et al., 1997). 색소함유량이 높은 반투명스테인은 UV로부터 보호효과가 확실히 커지지만 심미적 으로 기대하는 목리의 아름다움이 감추어지는 결점이 있어 색소함유수준이 중요하다고 소개하였다(Nejad \& Cooper, 2017; Knaebe, 2013). 색소함유량이 아주 높은 불투명한 스테인의 경우, UV가 거의 완전하게 차단될 뿐 아니라 바니시나 페인트에 서 보여지는 도막에 갈라짐이나 박리도 발생하지 않는 특성을 나타내었다(Feist, 1983). 함침형 스테인의 내구성 기능은 색소함량, 수지함량, 보존제, 발수제 및 스테인 도포량 등의 인자에 의한 영향이 크고 이들 인자들이 적절히 구성된 스테인시스 템을 적용하여 기상열화 방지에 좋은 결과로 있었다는 연구결과들이 소개되었다(Rowell, 2013; Feist, 1983; Bufkin \& Wildman, 1980; Feist \& Mraz, 1980). 실제로 내구성이 약한 목재를 수분이 많은 환경에서 발수제와 목재보존제를 함유한 함침형의 발수성스테인을 사용하거나 유성의 반투명스테인을 적용했을 때 발수성이 우수하여 기상열화 방지에 효과적이라고 한다(Knaebe, 2013). 특히 소수성의 유성발수제나 수지기반의 발수제와 같은 왁스 도장이 90 도이상의 접촉각을 가질 정도의 방수효과가 높다고 하는 예도 있고, 이 밖에 Polyvinylidene fluoride(PVDF) 등의 수지, UV stabilizers나 항균성약제 들을 첨가하여 기상열화 방지를 꾀하기도 하는 연구들이 다수 보고되고 있다(Landry et al., 2013; Landry \& Blanchet, 2012; Kiguchi et al., 1997).

\section{4. 화학적 개질 처리}

이상에서 소개된 기상열화 방지 방법 외에 다양한 방법들이 연구되었다. 목재에 화학적 개질 처리를 실시하여 목재의 친수성을 감소시킴으로서 수분변화에 따른 치수안정성을 높이고 기상열화에 대한 저항성을 높이는 연구들이 보고되었다. 즉, Methylation, acetylation 또는 alkylation 등과 같은 화학적 개질 처리로 인해 목재에 퀴논이 형성됨으로써 페놀성 수산기를 차단시키는 효과로 인해 빛에 의한 목재표면의 색상안정성이 개선효과가 있다는 것이다(Rowell et al., 2009; Hill, 2006; Ohkoshi, 2002; Beckers et al., 1998; Kalnins, 1984). Acetyl화로 인한 중량증가가 10 20\%정도로 처리된 acetyl화목재는 노란색 광열화, 할열 및 표면침식 등을 감소시키는 효과가 있다(Pandey \& Pitman, 2002; Evans et al., 
2000a; Plackett et al., 1992; Dunningham et al., 1992; Feist et al., 1991 핸드북문헌). 특히 acetyl화로 인한 중량증가가 $20 \%$ 이상이 되면 기상열화로부터 목재가 보호되어 acetyl화 처리 수준이 기상열화 방지효과에 영향함이 시사되었다 (Alfredsen et al., 2013). Ohkoshi et al.(2002)은 acetyl화목재의 기상열화에 대한 저항성을 개선하기 위해 acetyl화 처리와 polyethylene glycol methacrylate처리를 복합하는 방법을 시도하여 목재의 색상변화 감소 및 표면 할열 등의 감소가 있었다 고 보고하였다. 이와 같이 Acetyl화 처리는 다양한 화학 수식 중에서 기상열화에 대한 저항성이 비교적 우수한 것으로 보고되고 있으나, 장기간 기상조건에 노출되었을 때는 표면의 acetyl기가 이탈되면서 광열화현상이 증가되는 현상이 발생 한다는 보고들이 있다(Gobakken \& Westin, 2008; Evans et al., 2000a). 더구나 acetyl화 하는 과정에서 발생하는 초산이 목재에 잔유하면서 목재성분의 산화를 촉진된다는 보고도 있고, acetyl화 처리가 야외의 기상조건에 노출될 때 목재조직의 열화 및 기상열화에 대한 저항성을 크게 개선하지 못한다고 보고도 다수 있어 향후 더 깊은 연구가 요구된다(Rowell, 2013; Imamura, 1993; Kalnins, 1984).

이 밖에 succinic 또는 proprionic 무수물, phthalic 무수물, 방향족 vinyl ester, vinyl bnzoate 등을 사용하여 ester화처리(핸드북 문헌 Bhat et al., 2010; Murakami \& Matsuda, 1990), benzyl화처리(Pandey \& Chandrashekar, 2006; Evans et al., 2002; Kiguchi, 1990), Styrene 및 methylmethacrylate 등의 중합 가능한 단량체, phenol formaldehyde resin 및 melamine formaldehyde resin 등의 물질을 목재에 주입했을 때 외부 사용에서 목재의 변색, 갈라짐 및 빛에 의한 열화로부터 보호할 수 있는 방법들도 보고되었다. (Sudiyani et al., 2001; V‘Ichera 1986; Pittman et al., 1992; Rapp \& Peek, 1999; Hansmann et al., 2006).

\section{5. 열처리}

열처리가공은 무산소 상태에서 $200^{\circ} \mathrm{C}$ 이상의 고온으로 3 7시간 처리로 목재의 물리화학적 성질을 개조하여 목재의 치수안 정성과 내후성을 개선시키는 목적으로 시행되는 목재가공방법 중의 하나이다(Esteves \& Pereira, 2009). 열처리가공과정에서 고온으로 인한 화학적 변화로 목재 중 - $\mathrm{OH}$ 기 감소로 인하여 소수성이 증가함으로 목재표면의 방수효과가 커서 표면의 성능이 좋은 특성이 있다(Nejad et al., 2012; Petrissans et al., 2003). 그러나 열처리목재의 기상열화에 대한 저항성에 대해서는 여러 가지 상반되는 연구결과 들이 보고되고 있다. Huang et al.(2012)은 열처리목재라 하더라도, 기상에 노출되는 목재성분, 즉, 셀루로우스의 결정영역이 비결정화되는 현상 등으로 친수성기가 증가하여 표면의 젖음성이 증가함을 보고하였다. Ayadi et al.(2003)과 Shi \& Jiang(2011)은 열처리목재를 외부에서 짧은 시간 기상에 노출되었을 때 색상 변화 및 표면침식이 무처리에 비해 적고, A. pullulans와 같은 변색균의 방지에도 효과가 있는 것으로 보고하였다(Feist \& Sell, 1987). 그러나 Wolkenhauer et al.(2008) 과 Awoyemi et al.(2009)은 열처리에 의한 기상열화에 대한 개선효과가 없음을 보고하였고, 일부 연구보고들은 무처리에 비해 도장성이 감소했다고 보고하였다(Nejad et al., 2012; Petrič et al., 2007; Jämsä et al., 2000). 열처리한 Ash와 Iroko는 자연내후조작의 기간이 길어질수록 밝은 은색으로 변화되었고, 열처리한 Scots pine은 초기 18 개월간은 어두운 색으로 변하다가 24개월 정도 경과했을 때 은회색으로 변화되는 현상이 있었다고 보고하였다. Xing et al. (2015)는 열처리목재라 하더라도, 기상 노출의 초기에는 무처리재에 비해 기상열화저항성이 향상되나 장기적으로는 기상열화에 대한 저항성이 낮음을 보고하였다. 또한 자연내후조작 후 열처리목재의 MOR도 감소하고, 심지어는 변색균의 오염도 발생했다는 보고가 있다 (Tomak et al., 2014). 실제로 열처리재에 대한 많은 보고에서 열처리목재가 방부목재에 비해 흡수성이 낮은 특징이 있음을 보고하고 있으나 실제로 무처리재와 거의 동등한 수준으로 회색화되는 기상열화가 발생했다고 보고되었다(Dubey et al., 2010; Nejad \& Cooper, 2013). Nejad et al., 2017)는 열처리목재의 경우, 방부목재보다 더 강력한 UV저항성을 지닌 제제의 도료를 사용한 도장의 필요하다고 강조하였다.

\section{6. 결 론}

주요 기상열화 인자(weathering factors)로부터 목재의 표면 보호를 위한 각종 가공기술의 연구 동향에 대하여 조사한 결과 다음과 같은 결론을 얻었다.

1. 목재보존제(wood preservatives)로 사용된 크롬, 구리 등의 무기화합물이 목재를 기상열화(weathering)로부터 보호할 수 있는 것으로 보고되었다. 그러나 ACQ의 경우, 구리-amine착화합물 또는 산화구리가 자외선에 의한 리그닌 등의 광산화(photo-oxidation) 저해 기능이 있으나, 일부 alkyl ammonium화합물로 인한 친수성으로 자외선 침투깊이 (penetration depth)가 증가되어 기상열화 방지효과가 약화될 수 있는 것으로 보고되었다.

2. ACQ처리목재(treated wood with ACQ)의 표면에 wax나 oil같은 소수성물질과 UV 흡수제 등이 첨가된 도료로 도장하거 
나, 목재 내 자유라디칼(free radicals) 제어 기능이 있는 HALS(Hindered Amine Light Stabilizers) 등을 프리코트 (precoating)하면 기상열화 저항성을 강화할 수 있다고 보고되었다. 방부목재(treated wood with wood preservatives) 표면에 불투명(opaque) 도막형성(film-formation)의 페인트/스테인 및 반투명스테인(semi-transperent stain) 등을 도장 처리 했을 때 기상열화방지에 대한 시너지 효과가 높다는 보고들이 다수 있었다. 또한 방부목재의 표면보호를 위한 재도장 처리(refinish)의 필요성이 시사되었다.

3. 기상열화 인자로부터 목재표면을 보호하는데 다양한 도료의 표면도장 효과가 소개되었다. 페인트, 바니시, 락카 등의 도막형성형 도장에서는 착색제가 UV차폐기능을 상당히 향상시킬수 있고, 발수성을 지닌 라텍스페인트의 우수성도 보고 되었다. 또한 투명성의 도막에 $\mathrm{UV}$ 방지를 위한 첨가물로서 미세입자의 $\mathrm{ZnO}$ 또는 $\mathrm{TiO}_{2}, \mathrm{Co}, \mathrm{Cr}, \mathrm{Fe}, \mathrm{Mn}, \mathrm{Ni}$ 과 $\mathrm{Ti}$ 등의 금속이온, Tris-resorcinol triazine derivatives, triazine 및 Benzotriazole와 같은 UV흡수제 등이 소개되었다. 함침형의 표면도장에서는 불투명스테인을 제외한 반투명 또는 투명스테인의 경우에는 양질의 표면보호를 위해 발수제, 항균제, $\mathrm{UV}$ 안정제나 $\mathrm{UV}$ 차단제 등의 첨가물이 필요한 것으로 나타났다.

4. Methylation, acetylation 또는 alkylation 등과 같은 화학적 개질 처리의 경우에는 화학적 개질 처리로 인한 중량증가가 높은 경우 기상열화 방지효과가 상승된다는 연구들이 소개되었다, 그러나 acetyl화 목재의 경우, 목재에 잔유하는 초산이 야외노출에서 목재성분의 산화를 촉진하여 기상열화저항성 개선이 크지 않고, 장기간 노출에서는 화학적 개질 처리 부위가 표면에서 분해되거나 이탈되어 효과가 저하된다는 보고도 있어 보다 심화된 연구가 요구되는 것으로 고찰하였다.

5. 열처리목재의 기상열화 저항성에 대해서는 여러 가지 상반되는 연구보고 들이 있었다. 열처리목재는 열처리과정에서 목재 중 $-\mathrm{OH}$ 기 감소로 인하여 소수성이 증가하여 표면의 방수성능이 좋은 특성이 있고, 짧은 시간 자연노출에서 무처리에 비해 색상변화와 미생물피해가 적다는 보고도 있었으나, 뚜렷한 기상열화에 대한 저항성이 없어 UV저항성을 지닌 도장 의 필요성이 강조된 보고가 있어 보다 심도있는 연구의 필요성이 시사되었다. 